\title{
Nexus between Financial Fundamentals and Automotive (Car) Industry. ARDL approach
}

\author{
Asep Risman ${ }^{1}$, Muhammad Imtiaz Subhani², and Denis Ushakov ${ }^{3, *}$ \\ ${ }^{1}$ Universitas Mercu Buana, Jakarta-Indonesia \\ ${ }^{2}$ ILMA University, Karachi, Pakistan \\ ${ }^{3}$ Suan Sunandha Rajabhat University, Bangkok, Thailand
}

\begin{abstract}
This paper is an attempt to investigate the nexus between the financial fundaments and the market share of automotive(car) industry of top 26 automotive producing nations. The time series data of change is stock prices, trading volumes of stocks and market shares of automotive industry of top 26 automotive producing nations were collected from data stream Eikon for the period from 2002 to 2014. ARDL approach was used to investigate the lag length nexus of financial fundaments with the market shares of automotive(car) industry. Further AR processes were also investigated for the series of automotive market shares. Findings confirmed the significant impact of change in stock prices on the Automobile (car) Market Sharesfor France, Hungary, Indonesia, Malaysia, Romania, South Africa, South Korea, Turkey and United States of America for lag1, while alsothe significant impact of change in stock priceson the Automobile (car)Market Shares were also found present for China, France, Hungary, Indonesia, Italy, Malaysia, Pakistan, Romania, South Africa and South Korea for lag 2. Findings further confirmed the impact of trading volumes for lag1 on the Automobile (car) Market Sharesfor Argentina, Brazil, France, Hungary, India, Italy, Japan, Pakistan, South Africa, South Korea and Taiwan. The impact of trading volumes for lag2 on the Automobile Market(car) Sharewere also found present for Brazil, Hungary, India, Italy, Romania, South Africa, Ukraine, United Kingdom and United States of America. Moreover, AR processes in market shares of automotive (car) industry for few from the outlined nations were also observed for the stated period.
\end{abstract}

\section{Introduction}

Automobile sector acts as a catalyst to empower economic growth in the country with employment opportunities. The automotive industry is one of the leading economic drivers of the World; it holds a great chunk of expansion, strength and cohesion to the microeconomic zone and that is why the automotive industry is acclaimed as one of the elements in building and fostering a nation. Enabling Research, Innovation \& Development, accelerating economic growth, bringing governments' revenue, generating employment

\footnotetext{
*Corresponding author: denis.us@ssru.ac.th
} 
opportunities are some of the positive shifts that come into motion due to the automobile industry operations $[1,2]$.

The primary objective of this paper is to investigate the investigate the relationship between the Financial fundaments (i.e. change is stock prices and trading volume of stocks at equity markets) and the market share of automotive industry of top 26 automotive producing nations through auto regressive distributed lag (ARDL) approach. While Auto regressive process is also planned to interrogate while deploying the same ARDL model.

\section{Literature Review}

In the automobile industry, market share provide an ample view about the automobile firms' market leader in various market segmentations and in greater detail it identifies the aggregate production, manufacturing cost for firms', which attain a higher market share and indeed in this established industry of existing automobile giants since decades, it is extremely difficult to gain one's market share.

Like any other industry, automobile industry also has to carry out contingency planning and right marketing strategies, strategic program etc to gain the market share. Hence, the business, marketing and development managers usually tap unsatisfactory market position to gain volume profits and profitability [3].

Market share as represented by the sales of a particular industry; studying the US auto sector revealed sales, which was much better in year 2000 than 2011. The reasons behind the sales fall was due to the fall in total demand and long-term decline in the market share [4].

$[5,6]$ analyzed the stock markets of Hong Kong, Singapore, Japan, Australia, and USA and its connections with their automotive markets. The study notes that stock-market interlinkages became more strengthened as after the Asian financial crisis of 1997. Furthermore, the study identifies significant spillover of US market-volatility into the Asian markets, while spillover from the Japan markets is identified to be comparatively weaker and during all these events automotive markets commoved with the stated equity markets.

$[7,8]$ examined the integration between the markets of Sri Lanka, India, and Pakistan by analyzing data ranging 2003-2010 and its possible connections with automotive industry of these nations.

\section{Research Methodology}

\subsection{Description of selected Variables, Data and Hypotheses}

As mentioned earlier that the main focus of this paper is to evaluate and investigate the nexus or the associations between the financial fundaments and the market share of automotive industry of top 26 automotive producing nations. Where change is stock prices and trading volume of stocks at equity markets are taken as the proxies to represent the financial fundaments. The time series data of change is stock prices, trading volumes of stocks and market shares of automotive industry of top 26 automotive producing nations are collected from data stream Eikon for the period from 2002 to 2014. The top 26 automotive producing nations taken in this study are mentioned in the following table. 
Table 1. Top 26 automotive producing nations.

\begin{tabular}{|l|l|l|l|}
\hline 1: Argentina & 8: Germany & 15: Mexico & 22: Taiwan \\
\hline 2: Australia & 9: Hungary & 16: Poland & 23: Turkey \\
\hline 3: Brazil & 10: India & 17: Romania & 24: Ukraine \\
\hline 4: Canada & 11: Indonesia & 18: Russia & 25: UK \\
\hline 5: China & 12: Italy & 19: S. Africa & 26: USA \\
\hline 6: Czech Republic & 13: Japan & 20: S. Korea & \\
\hline 7: France & 14: Malaysia & 21: Spain & \\
\hline
\end{tabular}

\subsection{Hypotheses established}

The hypotheses which are established to test the proposition of this study include:

H1: There is an effect of change in stock prices on the automotive total market share of top automotive (cars) manufacturing nations.

$\mathrm{H} 2$ : There is an effect of trading volume of stocks on the automotive total market share of top automotive (cars) manufacturing nations.

H3: There is an AR process in the total market share of automotive (car) industry of the top automotive producing nations when the panel of variables for equity/ stock markets /independent variables are change in stock prices and trading volume.

The above all three hypotheses are tested for all outlined top 26 automotive producing nations.

\subsection{Description of the econometric model deployed to test hypotheses}

ARDL approach is used to investigate the lag length effect of financial fundaments i.e. change is stock prices and trading volume of stocks at equity markets, on the market shares of automotive industry. Further AR processes are also investigated for the series of automotive market shares of all outlined industry/ nations.

\section{Findings and Results}

Findings in the above table also confirms the impact of change in stock price for previous period (lag1) on the Automobile Market Share for current period (lag0) for France, Hungary, Indonesia, Malaysia, Romania, South Africa, South Korea, Turkey and United States of America while the impact of change in stock price for previous to previous period (lag2) on the Automobile Market Share for current period (lag0) was also found present for China, France, Hungary, Indonesia, Italy, Malaysia, Pakistan, Romania, South Africa and South Korea. 
Table 2. Results and findings on lag length effects of change in stock prices on market shares of automotive industry/ nations.

\begin{tabular}{|c|c|c|c|c|c|c|}
\hline \multicolumn{2}{|c|}{$\begin{array}{c}\text { Statement of } \\
\text { hypotheses }\end{array}$} & EMP concl & & EMP concl & & EMP concl \\
\hline \multirow{18}{*}{$\begin{array}{l}\text { There is } \\
\text { an effect } \\
\text { of } \\
\text { change } \\
\text { in stock } \\
\text { prices } \\
\text { on the } \\
\text { automot } \\
\text { ive total } \\
\text { market } \\
\text { share of } \\
\text { top } \\
\text { automot } \\
\text { ive } \\
\text { (cars) } \\
\text { manufac } \\
\text { turing } \\
\text { nations. }\end{array}$} & \multirow{2}{*}{ 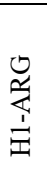 } & $\begin{array}{l}\text { Failed to reject for } \\
\text { lag1 (R) }\end{array}$ & \multirow{2}{*}{$\underset{\substack{\text { Z } \\
0}}{\stackrel{1}{\Xi}}$} & $\begin{array}{l}\text { Failed to reject for } \\
\text { lag1 (R) }\end{array}$ & \multirow{2}{*}{ 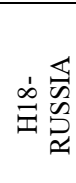 } & $\begin{array}{c}\text { Failed to reject for } \\
\text { lag1 (R) }\end{array}$ \\
\hline & & $\begin{array}{l}\text { Failed to reject for } \\
\text { lag2 (R) }\end{array}$ & & $\begin{array}{l}\text { Failed to accept } \\
\quad \text { for lag2 }(\mathrm{R})\end{array}$ & & $\begin{array}{l}\text { Failed to accept for } \\
\text { lag2 (R) }\end{array}$ \\
\hline & \multirow{2}{*}{ 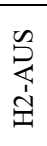 } & $\begin{array}{l}\text { Failed to accept } \\
\text { for lag1 (R) }\end{array}$ & \multirow{2}{*}{ 主合 } & $\begin{array}{l}\text { Failed to accept } \\
\text { for lag1 } 1(\mathrm{R})\end{array}$ & \multirow{2}{*}{ 宣䍃 } & $\begin{array}{l}\text { Failed to accept for } \\
\text { lag } 1(\mathrm{R})\end{array}$ \\
\hline & & $\begin{array}{l}\text { Failed to accept } \\
\text { for lag2 (R) }\end{array}$ & & $\begin{array}{l}\text { Failed to accept } \\
\text { for lag2 (R) }\end{array}$ & & $\begin{array}{c}\text { Failed to accept for } \\
\text { lag2 (R) }\end{array}$ \\
\hline & \multirow{2}{*}{ 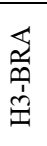 } & $\begin{array}{l}\text { Failed to reject for } \\
\text { lag1 (R) }\end{array}$ & \multirow{2}{*}{ 主莺 } & $\begin{array}{c}\text { Failed to reject for } \\
\text { lag1 (NR) }\end{array}$ & \multirow{2}{*}{ 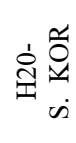 } & $\begin{array}{c}\text { Failed to accept for } \\
\text { lag1 (R) }\end{array}$ \\
\hline & & $\begin{array}{l}\text { Failed to reject for } \\
\text { lag2 (R) }\end{array}$ & & $\begin{array}{l}\text { Failed to reject for } \\
\text { lag2 (NR) }\end{array}$ & & $\begin{array}{c}\text { Failed to reject for } \\
\text { lag2 (R) }\end{array}$ \\
\hline & \multirow{2}{*}{ 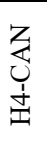 } & $\begin{array}{l}\text { Failed to reject for } \\
\text { lag1 (R) }\end{array}$ & \multirow{2}{*}{ 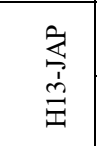 } & $\begin{array}{l}\text { Failed to accept } \\
\text { for lag1 (R) }\end{array}$ & \multirow{2}{*}{ 文芯 } & $\begin{array}{c}\text { Failed to accept for } \\
\text { lag1 (R) }\end{array}$ \\
\hline & & $\begin{array}{l}\text { Failed to reject for } \\
\text { lag2 (R) }\end{array}$ & & $\begin{array}{l}\text { Failed to accept } \\
\text { for lag2 (R) }\end{array}$ & & $\begin{array}{c}\text { Failed to reject for } \\
\text { lag2 }(\mathrm{R})\end{array}$ \\
\hline & \multirow{2}{*}{ 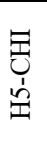 } & $\begin{array}{l}\text { Failed to accept } \\
\text { for lag1 (R) }\end{array}$ & \multirow{2}{*}{ 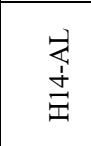 } & $\begin{array}{l}\text { Failed to accept } \\
\text { for lag1 (NR) }\end{array}$ & \multirow{2}{*}{ さ̇飞 } & $\begin{array}{c}\text { Failed to reject for } \\
\text { lag1 (R) }\end{array}$ \\
\hline & & $\begin{array}{l}\text { Failed to accept } \\
\text { for lag2 (R) }\end{array}$ & & $\begin{array}{l}\text { Failed to accept } \\
\text { for lag2 (NR) }\end{array}$ & & $\begin{array}{c}\text { Failed to accept for } \\
\text { lag2 (R) }\end{array}$ \\
\hline & \multirow{2}{*}{ 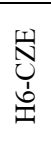 } & $\begin{array}{l}\text { Failed to reject for } \\
\text { lag1 (R) }\end{array}$ & \multirow{2}{*}{ 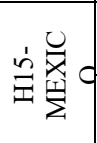 } & $\begin{array}{l}\text { Failed to accept } \\
\text { for lag1 (NR) }\end{array}$ & \multirow{2}{*}{$\stackrel{\text { }}{\tilde{y}}$} & $\begin{array}{l}\text { Failed to accept for } \\
\text { lag1 (NR) }\end{array}$ \\
\hline & & $\begin{array}{l}\text { Failed to accept } \\
\text { for lag2 (R) }\end{array}$ & & $\begin{array}{l}\text { Failed to accept } \\
\text { for lag2 (NR) }\end{array}$ & & $\begin{array}{c}\text { Failed to accept for } \\
\text { lag2 (NR) }\end{array}$ \\
\hline & \multirow{2}{*}{ 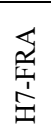 } & $\begin{array}{l}\text { Failed to accept } \\
\text { for lag1 (R) }\end{array}$ & \multirow{4}{*}{$\begin{array}{l}0 \\
0 \\
\vdots \\
0 \\
\Xi\end{array}$} & & \multirow{2}{*}{ 京孚 } & $\begin{array}{c}\text { Failed to accept for } \\
\text { lag1 (R) }\end{array}$ \\
\hline & & $\begin{array}{l}\text { Failed to accept } \\
\text { for lag2 (R) }\end{array}$ & & $\begin{array}{l}\text { Failed to accept } \\
\text { for lag1 (NR) }\end{array}$ & & $\begin{array}{c}\text { Failed to accept for } \\
\text { lag2 (R) }\end{array}$ \\
\hline & \multirow{2}{*}{ 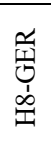 } & $\begin{array}{l}\text { Failed to reject for } \\
\text { lag1 }(\mathrm{R})\end{array}$ & & & \multirow{2}{*}{ 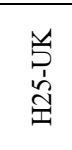 } & $\begin{array}{c}\text { Failed to reject for } \\
\text { lag1 (NR) }\end{array}$ \\
\hline & & $\begin{array}{l}\text { Failed to reject for } \\
\text { lag2 (R) }\end{array}$ & & $\begin{array}{l}\text { Failed to accept } \\
\text { for lag2 (NR) }\end{array}$ & & $\begin{array}{c}\text { Failed to reject for } \\
\text { lag2 (NR) }\end{array}$ \\
\hline & \multirow{2}{*}{ 芯 } & $\begin{array}{c}\text { Failed to reject for } \\
\text { lag1 (NR) }\end{array}$ & \multirow{2}{*}{ 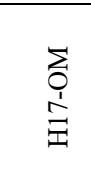 } & $\begin{array}{l}\text { Failed to accept } \\
\text { for lag1 (R) }\end{array}$ & \multirow{2}{*}{ 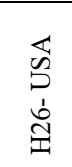 } & $\begin{array}{c}\text { Failed to accept for } \\
\text { lag1 (NR) }\end{array}$ \\
\hline & & $\begin{array}{l}\text { Failed to accept } \\
\text { for lag2 (NR) }\end{array}$ & & $\begin{array}{l}\text { Failed to accept } \\
\text { for lag2 (R) }\end{array}$ & & $\begin{array}{c}\text { Failed to accept for } \\
\text { lag2 (NR) }\end{array}$ \\
\hline \multicolumn{7}{|c|}{$\begin{array}{l}\text { Failed to accept at } \mathrm{t}<1.5 \\
\mathrm{R}=\text { Model is reliable } \\
\mathrm{NR}=\text { Model is not reliable } \\
\text { EMP CONCL = Empirical }\end{array}$} \\
\hline
\end{tabular}


Table 3. Results and findings on lag length effects of equity markets' trading volume on market shares of automotive industry/ nations.

\begin{tabular}{|c|c|c|c|c|c|c|}
\hline \multicolumn{2}{|c|}{$\begin{array}{l}\text { Statement of } \\
\text { hypotheses }\end{array}$} & EMP concl & & EMP concl & & EMP concl \\
\hline \multirow{18}{*}{$\begin{array}{l}\text { There is } \\
\text { an effect } \\
\text { of trading } \\
\text { volume of } \\
\text { stocks on } \\
\text { the } \\
\text { automotiv } \\
\text { e total } \\
\text { market } \\
\text { share of } \\
\text { top } \\
\text { automotiv } \\
\text { e (cars) } \\
\text { manufactu } \\
\text { ring } \\
\text { nations. }\end{array}$} & \multirow{2}{*}{ 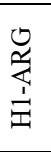 } & $\begin{array}{l}\text { Failed to accept } \\
\text { for lag1 (R) }\end{array}$ & \multirow{2}{*}{ 宫㝋 } & $\begin{array}{l}\text { Failed to accept } \\
\text { for lag1 (R) } \\
\end{array}$ & \multirow{2}{*}{ 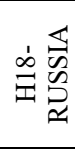 } & $\begin{array}{l}\text { Failed to accept } \\
\text { for lag1 (R) }\end{array}$ \\
\hline & & $\begin{array}{l}\text { Failed to accept } \\
\text { for lag2 (R) }\end{array}$ & & $\begin{array}{c}\text { Failed to reject for } \\
\text { lag2 (R) }\end{array}$ & & $\begin{array}{l}\text { Failed to accept } \\
\text { for lag2 }(\mathrm{R})\end{array}$ \\
\hline & \multirow{2}{*}{ 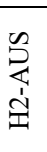 } & $\begin{array}{c}\text { Failed to reject for } \\
\text { lag1 (R) }\end{array}$ & \multirow{2}{*}{ 主尽 } & $\begin{array}{l}\text { Failed to accept } \\
\text { for lag } 1(\mathrm{R})\end{array}$ & \multirow{2}{*}{ 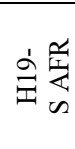 } & $\begin{array}{c}\text { Failed to accept } \\
\text { for lag1 }(\mathrm{R})\end{array}$ \\
\hline & & $\begin{array}{l}\text { Failed to accept } \\
\text { for lag2 (R) } \\
\end{array}$ & & $\begin{array}{l}\text { Failed to reject for } \\
\text { lag2 (R) }\end{array}$ & & $\begin{array}{l}\text { Failed to accept } \\
\text { for lag2 (R) }\end{array}$ \\
\hline & \multirow{2}{*}{ 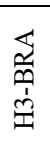 } & $\begin{array}{c}\text { Failed to reject for } \\
\text { lag1 (R) }\end{array}$ & \multirow{2}{*}{ 主志 } & $\begin{array}{l}\text { Failed to accept } \\
\text { for lag1 (NR) }\end{array}$ & \multirow{2}{*}{ 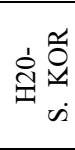 } & $\begin{array}{l}\text { Failed to reject } \\
\text { for lag1 }(\mathrm{R})\end{array}$ \\
\hline & & $\begin{array}{c}\text { Failed to reject for } \\
\operatorname{lag} 2(\mathrm{R})\end{array}$ & & $\begin{array}{l}\text { Failed to accept } \\
\text { for lag2 (NR) }\end{array}$ & & $\begin{array}{l}\text { Failed to reject } \\
\text { for lag2 }(\mathrm{R})\end{array}$ \\
\hline & \multirow{2}{*}{ 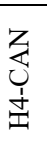 } & $\begin{array}{l}\text { Failed to accept } \\
\text { for lag1 (R) }\end{array}$ & \multirow{2}{*}{ 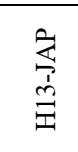 } & $\begin{array}{l}\text { Failed to accept } \\
\text { for lag1 (R) }\end{array}$ & \multirow{2}{*}{ 文芯 } & $\begin{array}{l}\text { Failed to accept } \\
\text { for lag1 }(\mathrm{R})\end{array}$ \\
\hline & & $\begin{array}{l}\text { Failed to reject for } \\
\text { lag2 (R) }\end{array}$ & & $\begin{array}{l}\text { Failed to accept } \\
\text { for lag2 (R) }\end{array}$ & & $\begin{array}{l}\text { Failed to accept } \\
\text { for lag2 }(\mathrm{R})\end{array}$ \\
\hline & \multirow{2}{*}{ 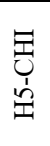 } & $\begin{array}{l}\text { Failed to accept } \\
\text { for lag1 (R) }\end{array}$ & \multirow{2}{*}{$\begin{array}{l}\underset{t}{+} \\
\stackrel{+}{ \pm} \\
\mathbb{I}\end{array}$} & $\begin{array}{l}\text { Failed to accept } \\
\text { for lag1 (NR) }\end{array}$ & \multirow{2}{*}{ さ̇さ } & $\begin{array}{c}\text { Failed to reject } \\
\text { for lag1 (R) }\end{array}$ \\
\hline & & $\begin{array}{l}\text { Failed to accept } \\
\text { for lag2 (R) }\end{array}$ & & $\begin{array}{l}\text { Failed to accept } \\
\text { for lag2 (NR) }\end{array}$ & & $\begin{array}{l}\text { Failed to accept } \\
\text { for lag2 }(\mathrm{R})\end{array}$ \\
\hline & \multirow{2}{*}{ 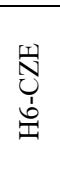 } & $\begin{array}{l}\text { Failed to reject for } \\
\text { lag1 (R) }\end{array}$ & \multirow{2}{*}{ 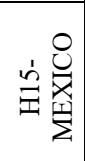 } & $\begin{array}{c}\text { Failed to accept } \\
\text { for lag1 (NR) }\end{array}$ & \multirow{2}{*}{ 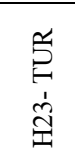 } & $\begin{array}{l}\text { Failed to accept } \\
\text { for lag1 (NR) }\end{array}$ \\
\hline & & $\begin{array}{l}\text { Failed to reject for } \\
\text { lag2 }(\mathrm{R})\end{array}$ & & $\begin{array}{l}\text { Failed to accept } \\
\text { for lag2 (NR) }\end{array}$ & & $\begin{array}{l}\text { Failed to accept } \\
\text { for lag2 (NR) }\end{array}$ \\
\hline & \multirow{2}{*}{$\begin{array}{l}\text { 壱 } \\
\text { 竞 }\end{array}$} & $\begin{array}{l}\text { Failed to accept } \\
\text { for lag1 (R) }\end{array}$ & \multirow{4}{*}{$\begin{array}{l}0 \\
0 \\
\text { م⿱宀 } \\
\Xi\end{array}$} & & \multirow{2}{*}{ 守壳 } & $\begin{array}{l}\text { Failed to reject } \\
\text { for lag1 }(\mathrm{R})\end{array}$ \\
\hline & & $\begin{array}{l}\text { Failed to reject for } \\
\text { lag2 (R) }\end{array}$ & & $\begin{array}{l}\text { Failed to accept } \\
\text { for lag1 (NR) }\end{array}$ & & $\begin{array}{l}\text { Failed to accept } \\
\text { for lag2 }(\mathrm{R})\end{array}$ \\
\hline & \multirow{2}{*}{ 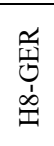 } & $\begin{array}{l}\text { Failed to accept } \\
\text { for lag1 (R) } \\
\end{array}$ & & & \multirow{2}{*}{$\begin{array}{l}\text { 光 } \\
\stackrel{1}{a} \\
\end{array}$} & $\begin{array}{l}\text { Failed to accept } \\
\text { for lag1 (NR) }\end{array}$ \\
\hline & & $\begin{array}{l}\text { Failed to reject for } \\
\text { lag2 (R) }\end{array}$ & & $\begin{array}{l}\text { Failed to accept } \\
\text { for lag2 (NR) }\end{array}$ & & $\begin{array}{l}\text { Failed to accept } \\
\text { for lag2 (NR) }\end{array}$ \\
\hline & \multirow{2}{*}{ 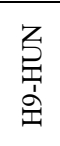 } & $\begin{array}{l}\text { Failed to accept } \\
\text { for lag1 (NR) }\end{array}$ & \multirow{2}{*}{$\begin{array}{l}\sum \\
0 \\
1 \\
I \\
\Xi\end{array}$} & $\begin{array}{l}\text { Failed to accept } \\
\text { for lag1 (R) }\end{array}$ & \multirow{2}{*}{ 它芯 } & $\begin{array}{l}\text { Failed to reject } \\
\text { for lag1 (NR) }\end{array}$ \\
\hline & & $\begin{array}{l}\text { Failed to accept } \\
\text { for lag2 (NR) }\end{array}$ & & $\begin{array}{l}\text { Failed to accept } \\
\text { for lag2 (R) }\end{array}$ & & $\begin{array}{c}\text { Failed to accept } \\
\text { for lag2 (NR) }\end{array}$ \\
\hline $\begin{array}{l}\text { Failed to re } \\
\text { Failed to ac } \\
R=\text { Model } \\
\mathrm{NR}=\text { Mode } \\
\text { EMP CON }\end{array}$ & $\begin{array}{l}\text { at } t \\
\text { t at } \\
\text { liab } \\
\text { not }\end{array}$ & $\begin{array}{l}1.5 \\
1.5 \\
\text { liable } \\
\text { pirical Conclusion }\end{array}$ & & & & \\
\hline
\end{tabular}


Table 4. Results and findings on AR process in market shares of automotive industry/ nations.

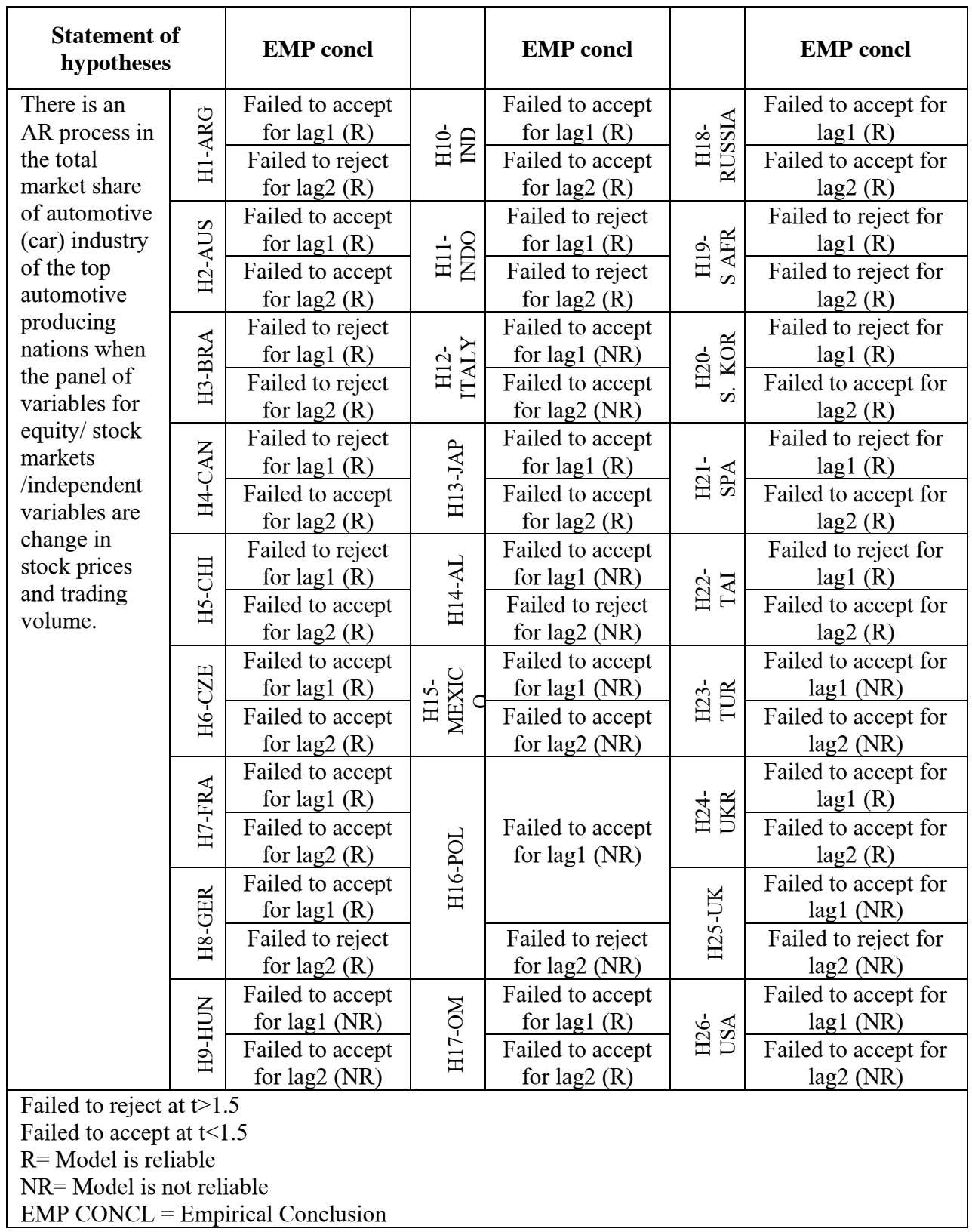

The table also confirms the impact of trading volume for previous period (lag1) on the Automobile Market Share for current period (lag0) for Argentina, Brazil, France, Hungary, India, Italy, Japan, Pakistan, South Africa, South Korea and Taiwan while the impact of trading volume for previous to previous period (lag2) on the Automobile Market Share for current period (lag0) was also found present for Brazil, Hungary, India, Italy, Romania, South Africa, Ukraine, United Kingdom and United States of America.

The ARDL model for addressing the explained relations between the Independent Variables and Dependent Variable were found substantially strong for Argentina, Australia, Brazil, Canada, China, France, Germany, Hungary, India, Indonesia, Japan, Malaysia, 
Mexico, Pakistan, Romania, South Africa, South Korea, Spain and United States of America nations as $\mathrm{R} 2 \geq 0.8$ with $\mathrm{F} \geq 3.84$.

Whereas ARDL model were not found substantially strong for explaining the stated relationships for Czech Republic, Italy, Poland, Russia, Taiwan, Turkey, Ukraine and United Kingdom, as $\mathrm{R} 2 \leq 0.8$ with $\mathrm{F} \leq 3.84$. it should be noted that the ARDL models were investigated via using the Schwarz SC criterion.

The findings confirms the presence of AR1 process (i.e. impact of Automobile Market Share for previous period (lag1) on the automobile Market Share for current period (lag0)) for Brazil, China, South Africa, South Korea and Taiwan, while the presence of AR2 process (i.e. impact of Automobile Market Share for previous to previous period (lag2) on the automobile Market Share for current period (lag0)) for Brazil, Hungary, Indonesia, Malaysia, South Africa and United Kingdom, as the t-statistics is observed more than 1.5 for the mentioned association.

\section{Conclusion}

This study concludes that there is the significant impact of change in stock prices on the Automobile Market Shares for most of the automotive (car) industry/ automotive (car) producing nations for both of the lags. Further, the impact of trading volumes of equity markets of all outlined nations on theirglobal Automobile(car) Market Shares were also found present for many nations for both lag and lag 2 for the selected period. Moreover, AR processes in market shares of automotive(car) industry for few from the outlined nations were also observed for the stated period.

\section{References}

1. G. Klink et al., The contribution of the automobile industry to technology and value creation (2013) /asset_publisher/dVxv4Hz2h8bS/ content/id/2427536)

2. A. Pongtiku et al., Scientific J. of Management and Business 4(3), 109 - 127 (2020)

3. C.D. Fogg, J. of Marketing 38(03), 30-38 (1974)

4. M. Scott et al., Southern Economic J. 64(4), 973-986 (1998)

5. S.J. Kim, J. of the Japanese and International Economies 19(3), 338-65 (2005)

6. B. Mulyana et al., Scientific J. of Management and Business Sl-1(3), 17-30 (2018)

7. H.T. Van et al., E3S Web of Conferences 175, 13034 (2020)

8. G.D. Sharma, B.S. Bodla, Asia- Pacific J. of Business Administration 3(2), 132 148 (2011) 